\title{
Architektura eksperymentalna w strukturach miejskich według ARCHItektonicznych teleGRAMÓW'
}

\author{
Arkadiusz Sarlej
}

\author{
STRESZCZENIE
}

Artykuł stara się wskazać przyczyny rozwoju architektury eksperymentalnej w drugiej połowie XX wieku. W tym czasie (po 1950) możemy zaobserwować bardzo dużą aktywność architektów i artystów poprzez projekty dotyczące życia i odczuć związanych z byciem tu i teraz, a także w dużej mierze w przyszłości. Powodami powstawania eksperymentalnych projektów są:

- niezadowolenie z sytuacji życiowej oraz politycznej - termin „sytuacja” został opisany oraz bardzo głęboko przeanalizowany przez Guy Deborda, który założył Międzynarodówkę Sytuacjonistyczną (1957), a wszystkie opisy mają charakter buntu,

- $\quad$ powstanie nowej filozofii życia, pracy i zabawy (na podstawie książki Johana Huinzingi Homo ludens. Zabawa jako źródło kultury -1938),

- $\quad$ bardzo gwałtowny postęp technologiczny (silna wiara np. w loty w kosmos, ruchome domy, życie pod wodą i nowe materiały budowlane) - pierwszy opis marzenia o ruchomym domu napisał Ivan Chtcheglov w 1953.

Bazując na powyższym, w roku 1961 powstaje Grupa Archigram, która w ciągu 13 lat wydała 10 numerów magazynów o tej samej nazwie, co posłużyło jako materiał badawczy (upublicznione oficjalnie pierwszy raz w całości) do przeanalizowania rozwoju myślenia o architekturze eksperymentalnej. Grupa poprzez swoje teksty, projekty, a także bardzo ciekawą oprawę graficzną była jedną z pierwszych, która ukazała inne eksperymentalne oblicze architektury i miast. Cały czas poszukiwała odpowiedzi na pytanie, jak zaprojektować przestrzeń, aby życie było jak najbardziej wygodne, a w związku z tym: szczęśliwe. Członkowie grupy nie znali ograniczeń w swoich futurystycznych projektach i głęboko wierzyli w to, że realizacja ich projektów będzie kwestią czasu. Tym bardziej, że założenia i koncepcje projektów były bardzo proste.

Po analizie numerów oraz projektów w nich zawartych widać, jaki duży wpływ grupa Archigram wywarła na współczesne projekty. Natomiast mimo ogromnego postępu technologicznego marzenia o zmiennym i mobilnym domu do dzisiaj są wciąż tylko marzeniem wielu twórców.

Słowa kluczowe: Archigram, architektura eksperymentalna, sytuacja, struktury urbanistyczne

Celem artykułu jest zapoznanie polskiego czytelnika z zawartością magazynów ARCHIGRAM wydawanych przez brytyjską grupę o tej samej nazwie w latach 1961-1974. Jest to możliwe dzięki opublikowaniu tych dokumentów, w pełnej postaci $\mathrm{w}$ formie elektronicznej, na oficjalnej stronie internetowej http://archigram.westminster. ac.uk/. Analiza magazynów, jako materiałów źródłowych, jest niezwykle istotna dla badania rozwoju architektury o charakterze eksperymentalnym. Przy czym chodzi zarówno o treść, jak i formę, która dla twórców awangardowych miała niezwykle istotne znaczenie. Dlatego ważną częścią badań analitycznych będą także okładki magazynów, stanowiązce integralny i spójny ich element. Dzięki metodzie analizy źródeł i analizie porównawczej wskazane

\footnotetext{
${ }^{1}$ Pełna nazwa magazynów, skrócona do takiej samej nazwy jak grupa Archigram.
} 


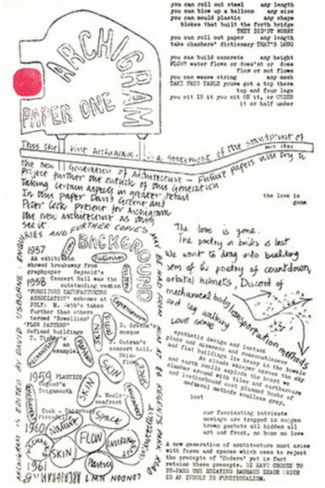

Ryc. 1. Okładka czasopisma

ARCHIGRAM nr 1, $1961 \mathrm{r}$.

Źródło: Archigram Archives, http://archigram. westminster.ac.uk/

zostaną różnorodne przyczyny rozwoju architektury i urbanistyki eksperymentalnej $\mathrm{w}$ drugiej połowie XX w.

W stuleciu tym wraz z szybkim rozwojem cywilizacyjnym i technologicznym na świecie zmieniło się podejście do architektury i urbanistyki w sferze wizualnej i teoretycznej. Grupa Archigram była jednym z wielu środowisk postulującycheksperymentalne podejście do architekturyiurbanistyki. Jest ono częścią większego procesu zachodzącego w latach 50. i 60. w Europie, którego celem był przewrót w świadomości zbiorowej. Guy Debord i jego zwolennicy chcieli go uzyskać poprzez tworzenie sytuacji kontrkulturowych, w których eksperyment ma niezwykle ważne znaczenie. Brytyjska grupa, choć miała związki z sytuacjonizmem² posiadała własną odrębność. Artykuł wskaże specyfikę brytyjskich twórców w kontekście rozwoju nowoczesnych metodologii projektowych, a także ich znaczenie dla rozwoju architektury eksperymentalnej. Pokaże również, że eksperymenty często czerpią swoje początki w dziedzinach filozofii i socjologii, mają także zabarwienie buntu. Artykuł jest wstępem do szerszych i głębszych rozważań na temat architektury eksperymentalnej, również w kontekście wielkich struktur sieciowych - urbanistycznych założeń projektowych grupy Archigram. Wskaże przyczyny, dla których eksperymentowi towarzyszy bunt oraz odniesie się skrótowo do konsekwencji pomysłów z lat 50. i 60. dla architektury czasów obecnych.

Wszystko zaczyna się od marzeń. Jeżeli je dobrze zdefiniujemy i włączymy $\mathrm{w}$ nasze rozwiązania nowe technologie, jesteśmy, być może, w stanie zmienićnaszą sytuację społeczną. Ukazuje to przykład opisu marzenia Ivana Vladimirovitcha Chtcheglova o mobilnym domu, w którym pokazuje mobilną zmienność sytuacji oderwanie się fizycznie i mentalnie od swojego położenia:

„Ostatnie osiagnnięcia technologiczne umożliwiłyby indywidualny, nieprzerwany kontakt z kosmiczną rzeczy-

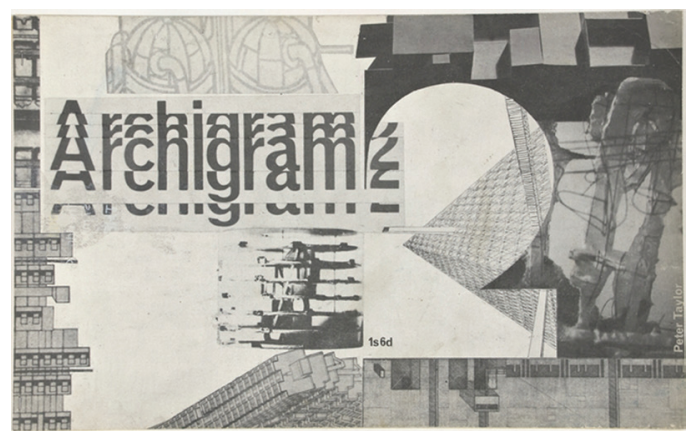

Ryc. 2. Okładka czasopisma ARCHIGRAM nr 2, 1962 r. Źródło: Archigram Archives, http://archigram.westminster.ac.uk/ wistością eliminując jednocześnie jej nieprzyjemne aspekty. Gwiazdy i deszcz można oglądać przez szklane sufity. Ruchomy dom budzi się wraz ze słońcem. Jego ruchome ściany umożliwiają żyć roślinom. Osadzony na kołach może udawać się w stronę morza rankiem i powracać w las wieczorem. Architektura jest najprostszym środkiem artykułowania czasu i przestrzeni, modulowania rzeczywistości, rodzenia marzeń" [Chtcheglov 1953].

\footnotetext{
${ }^{2}$ Sytuacjonizm odnosi się do terminologii organizacji Międzynarodówki Sytuacjonistycznej opisanej w artykule.
} 


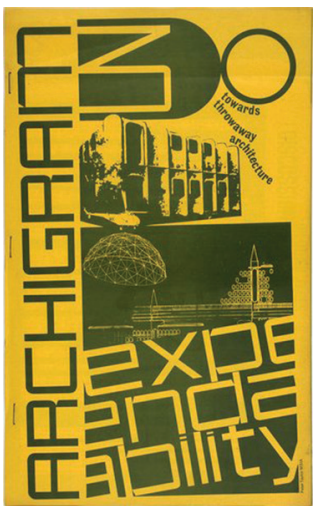

Ryc. 3. Okładka czasopisma ARCHIGRAM nr 3, jesień 1963 r.

Źródło: Archigram Archives, http://archigram.westminster.ac.uk/

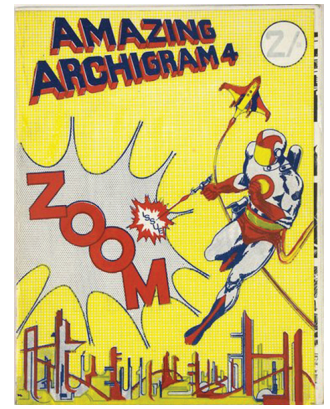

Ryc. 4. Okładka czasopisma ARCHIGRAM nr 4, wiosna 1964 r.

Źródło: Archigram Archives, http://archigram.westminster.ac.uk/

XX wiek obfituje $\mathrm{w}$ wiele zjawisk i postaci szukających odpowiedzi na sytuację politycznospołeczną panującą w Europie, a także na filozoficzne podejście do istnienia, a co z tym ściśle związane, do mieszkania w danym miejscu na Ziemi (życia w danej sytuacji). Artyści buntują się przeciwko temu. Definiują nieokreślane pojęcia i szukają szekspirowskiej zależności między życiem a bytem. „Wolność jest tylko w sytuacji, zaś sytuacja jest tylko za sprawą wolności" pisał J.P. Sartre w 1943 r. [Sartre 2007, s. 596].

Jednoznacznie pojęcie danej sytuacji oraz jej tworzenie opisał Guy Ernest Debord. Francuski filozof,pisarz, teoretyk polityczny, powołując Międzynarodówkę Letrystyczną pisał: „(...) zbudujemy poruszające miasta. Nowe piękno będzie SYTUACYJNE, to znaczy tymczasowe i przeżywane" [Debord 1954, w: Debord 2006, wstęp M. Kwaterko, s. 8]. Debord wraz ze swoją grupą ${ }^{3}$ stworzyli psychogeografię, której celem było tworzenie intymnej mapy miasta, opartej na emocjach konkretnych miejsc (psychotopologia). Znane miejsca odkrywamy na nowo dokonując innego spojrzenia na to samo miejsce. Sytuacjoniści wynaleźli "technikę" takiego spaceru po mieście - swobodne dryfowanie. Polega ono na tym, że chodząc po ulicach, podwórkach, alejach, kierujemy się siłą przyciągania architektury bez logicznego schematu i planu zwiedzania. Debord całymi dniami zabijając nudę spacerował po Paryżu, zapisywał wrażenia i wnioski. Bezcelowe z pozoru dryfowanie doprowadziło go do odkrycia nowego pożądanego piękna, które jest tu i teraz, w danej sytuacji, a więc jest sytuacyjne. Po założeniu Międzynarodówki Sytuacjonistycznej Debord pisał, że „pojęcie 'sytuacjonistyczny' to aktywność, której celem jest stwarzanie sytuacji, a nie ich bierne przyjmowanie lub ujmowanie za pomocą odseparowanych kategorii, na przykład akademickich. (...) Dotychczas filozofowie i artyści rozmaicie tylko opisywali sytuacje, chodzi jednak o to, aby je zmienić" [Debord 1964, w: Debord 2006, wstęp M. Kwaterko, s. 15].

Wiarę w nieograniczone możliwości technologiczne jutra na początku lat 50 . zapoczątkował Holender Constant (Constant Anton Nieuwenhuys) projektując utopijne

\footnotetext{
${ }^{3}$ Międzynarodówka Sytuacjonistyczna - „organizacja założona w 1957 r. we Francji przez G. Deobrda, skupiająca awangardowych twórców, którzy wspólnie formułowali radykalną i nowoczesną krytykę społeczną wymierzoną zarówno w wolnorynkowy kapitalizm, jak i w biurokratyczny socjalizm" - Mateusz Kwaterko na obwolucie Społeczeństwa spektaklu G. Deborda, 2006; organizacja wydała 12 numerów pisma Internationale situationniste w latach 1957-1969.
} 


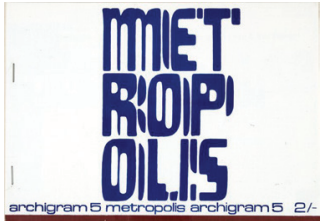

Ryc. 5. Okładka czasopisma ARCHIGRAM nr 5, jesień 1964 r. Źródło: Archigram Archives, http://archigram.westminster.ac.uk/

miasto Nowy Babilon. Na podstawie monografii holenderskiego historyka i antropologa kultury Johana Huizingi ${ }^{4}$, Constant tworzy gigantyczne futurystyczne miasto przyszłości, w którym wszyscy są obywatelami ziemi, nie ma granic administracyjnych ani podziałów politycznych, prace wykonują roboty i maszyny, natomiast ludzie (homo ludens) twórczo i kreatywnie spędzają czas na zabawach i grach, a codzienne czynności są dla nich formą sztuki. Miasto tworzą osiedla zawieszone nad istniejącymi miastami. „Nawet kiedy on [mieszkaniec przyp. autora] obejmuje wielkie odległości, homo faber [człowiek pracy - przeciwieństwo
homo ludens - przyp. autora] porusza się w przestrzeni społecznej ograniczonej obowiązkiem powrotu do stałego siedliska. Jest 'przywiązany do ziemi'. Jego relacje społeczne definiują jego przestrzeń społeczna która obejmuje jego dom, miejsce pracy, rodzinę oraz jego przyjaciół. Nowy Babilon rozwiązuje wymuszone więzi. Przestrzeń społeczna jest nieograniczona. Ponieważ nie jest on [mieszkaniec - przyp. autora] dłużej 'zakorzeniony', może krążyć swobodnie: znacznie bardziej swobodnie, ponieważ przemierza on przestrzeń w nieskończoność zmieniając przestrzeń i atmosferę w wyniku czego ona jest stale odnawiana. Mobilność i dezorientacja powoduja, umożliwiają kontakty między ludźmi. Więzi są wykonane i niewykonane bez żadnych trudności, obdarzone społecznymi relacjami z doskonałą otwartością. (...) Istotą kultury Nowego Babilonu jest zabawa elementami, które tworzą środowisko. Taka zabawa jest możliwa ze względu na integralną techniczną kontrolę wszystkich tych fragmentów, które stają się świadomym stworzeniem tego środowiska" [Constant 1960, w: Wigley 1998, s. 164].

Wyżej wymienione hasła dobrze inspirują do buntu, a także do eksperymentu w dążeniu do poszukiwań odpowiedzi na pytania: czym jest architektura? albo czym powinna się zajmować architektura? W latach 60. w Europie powstają studenckie grupy artystyczne. Odważni, którzy - nie bacząc na nic - z jednej strony buntują się, sprzeciwiają się założeniom Witruwiusza $^{5}$, z drugiej odrzucają (teoretycznie) motto modernistów „forma podąża za funkcją" [Sullivan 1896, s. 403-409]. Z tego buntu rodzą się nowe projekty i wymyślone nieznane formy oraz założenia podążające za d o w o l n o ś c i ą.

Jedną z takich grup, założonych w Wielkiej Brytanii w 1961 r., jest grupa Archigram. Praktycznie od momentu powstania zaczynają wydawać magazyn o nazwie swojej grupy „ARCHIGRAM", dzięki któremu możemy zrozumieć, jaką misję mieli młodzi zbuntowani

\footnotetext{
${ }^{4}$ Constant oparł się na książce Johana Huizingi, Homo ludens. Zabawa jako źródło kultury.

${ }^{5}$ Witruwiusz, $O$ architekturze ksiag dziesięć, 25 r. p.n.e. Księga pierwsza, rozdział trzeci. Autor pisze o trzech filarach budynku: trwałości, celowości (funkcji) i pięknie: „Przy budowie należy uwzględniać: trwałość, celowość i piękno. Trwałość budowli osiągnie się wtedy, gdy fundamenty doprowadzi się do stałego gruntu i gdy spośród wielu materiałów budowlanych przeprowadzi się wybór starannie, nie kierując się skąpstwem. Celowość zapewni się budowli przez bezbłędne rozplanowanie przestrzeni, nie ograniczające możliwości użytkowania i uwzględniające strony świata odpowiednie do przeznaczenia budynków. Piękno będzie zapewnione, jeśli wygląd budowli będzie miły i wykwintny, a wymiary poszczególnych członów oparte będą na właściwych zasadach symetrii".
} 
brytyjscy studenci. Pierwotnie ulotki - manifesty, hasła $\mathrm{w}$ formie telegramów o architekturze stały się z czasem poważnymi magazynami zagłębiającymi się w coraz to nowe pomysły, projekty i idee adresowane do szerszej publiczności. Peter Cook, David Greene i Michael Webb, a następnie Warren Chalk, Dennis Crompton i Ron Herron razem tworzą nową awangardę architektoniczną. Jak pisał Kristin Fedders „Nazwa czasopisma nie tylko sugerowała bezpośredniość przekazu w formie telegramu i wagę ich pomysłów, ale także opisywała ulotkowy format raczkujących publikacji" [Fedders 2004, s. 57].

Kultura masowa, wolnościowe przemiany społeczne, a przede wszystkim rozwój technologiczny inspirowały architektów do utopijnych projektów

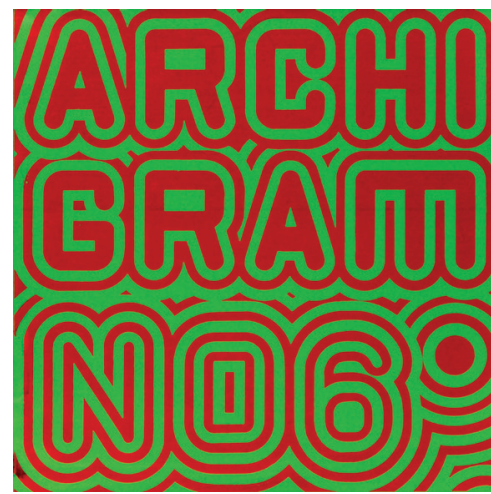

Ryc. 6. Okładka czasopisma ARCHIGRAM nr 6, jesień 1965 r. Źródło: Archigram Archives, http://archigram.westminster.ac.uk/ opisujących zmienne, różnorodne elementy połączone w superstruktury.

Zostało wydanych łącznie dziesięć numerów ARCHIGRAMU w latach 1961-1974. Każdy egzemplarz był inny, o różnych niestandardowych formatach, w różnych szatach graficznych ze zmiennym kolorem tła i liter. Często względy ekonomiczne decydowały o wyborze tańszego tuszu zielonego niż czarnego. Grafika, teksty oraz rysunki i zdjęcia tworzyły jedną całość przekazu. Niektóre numery miały wkładki, rozkładane wewnętrzne makiety albo kieszonkę z umieszczonym opornikiem elektrycznym. Część numerów miała tytuł przewodni, któremu było podporządkowane całe wydanie. Główną wartością merytoryczną są artykuły o nowej generacji architektury podparte przykładami projektów oraz konkursów autorów oraz zaproszonych gości (ryc. 1-10).

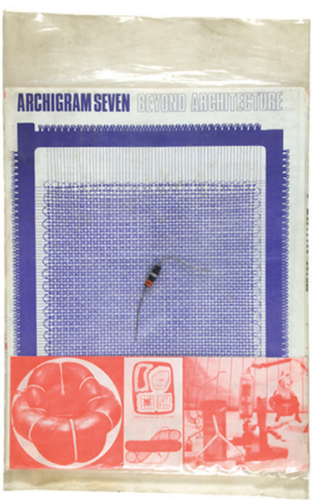

Ryc. 7. Okładka czasopisma

ARCHIGRAM nr 7, $1966 \mathrm{r}$.

Źródło: Archigram Archives, http://archigram.westminster.ac.uk/

Pierwszy numer (1961 r.) to dwie kartki papieru o różnych formatach (A4 i A3), wydany w liczbie 300 egzemplarzy, pisany ręcznie i maszynowo, połączony zszywką. $\mathrm{Na}$ pierwszej stronie czerwony stempel z ziemniaka. Był to sprzeciw i jednocześnie przesłanie dla wszystkich twórców i architektów, zawierające się w następujących słowach:

„możesz rozwinąć arkusz blachy - dowolnej długości możesz nadmuchać balon - dowolnej wielkości możesz uformować plastik - w dowolny kształt możesz rozwinąć papier - dowolnej długości możesz budować z betonu - dowolnej wysokości możesz utkać materiał - w dowolny splot możesz siedzieć w stole, na stole, pod stołem albo w połowie pod. 
Nowa generacja architektury musi powstać z form, które wydają się negować założenia modernizmu, ale w istocie je zachowują. Postanowiliśmy obejść rozpadający się wizerunek Bauhausu, który jest zniewagą dla funkcjonalizmu" [Greene 1961, s. 1].

Było to bardzo śmiałe i odważne założenie. Stwierdzenia, że mamy nieograniczone możliwości do kreowania architektury było ciosem w konserwatywny świat architektów i architektury brytyjskiej. Jasno z niego wynikało, że Archigram ma misję i jest nią ciągłe poszukiwanie odpowiedzi na nowe problemy zmieniającego się świata. Sami jeszcze nie wiedzieli, jak ich tezy znajdą zastosowanie w dekonstruktywizmie w późnych latach XX $\mathrm{w}^{6}$. Rozwinięty arkusz blachy, nadmuchany jak balon, nasuwa na myśl dzisiaj zrealizowane projekty Franka Gehrego, a beton dowolnej wysokości - np. Wieżę Holokaustu w Berlinie zaprojektowaną przez Daniela Libeskinda.

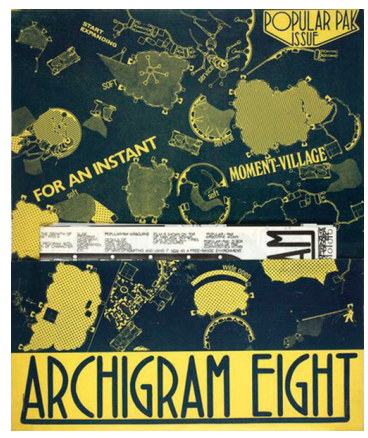

Ryc. 8. Okładka czasopisma ARCHIGRAM nr 8, $1968 \mathrm{r}$.

Źródło: Archigram Archives, http://archigram.westminster.ac.uk/

Przełomowym w karierze Grupy momentem stała się wystawa Living City w londyńskim Instytucie Sztuki Współczesnej, która zbiegła się z wydaniem trzeciego numeru jesienią 1963 r. Cały numer był poświęcony możliwościom zmian, jakie mogą zachodzić w miastach i ich użytkownikach. Zwyczaje spowodowane, np. wyrzucanym opakowaniem po jedzeniu powinny skłonić do zmiany stylu życia mieszkańców, na których odbija się ciągłe kupowanie i wyrzucanie - konsumpcjonizm. Wystawa pokazywała, że architektura jest tylko jednym z elementów miasta; miasto żyje dzięki mieszkańcom, ruchowi, komunikacji. W magazynie twórcy pisali: „wystawa Living City jako obiekt oczywiście zdezorientuje wielu ludzi, którzy lubią twórczą pracę i urbanistykę" [Grupa Archigram 1963, s. 7]. W zielonych kolorach na żółtym papierze grupa wytyka błędy modernizmowi. Wskazują na to, że błędnym, wręcz heroicznym założeniem są stałe potrzeby mieszkańców, które się jednak zmieniają. Nowocześnie znaczy z możliwością zmian. Cały numer - podobnie jak pozostałe - jest retoryczny, ale także przesycony poczuciem czarnego humoru. Podtytuł w stronę wyrzuconej architektury złośliwie nawiązuje do dzieła Le Corbusiera, podkreślając słuszność wskazanych racji. W numerze oglądamy domy-kapsuły (więcej o tym w numerze 4), projekt kapsuły Buckminstera Fullera, zmienne systemy mieszkalne. Autorzy pytają czy to jest architektura, którą można rozbudować w struktury, czy można ją potem zmienić?

Kolejne numery 4 i 5 - choć w różnych stylistycznych odniesieniach - poruszają w bardziej szaleńczy i odważny sposób temat miast jako metropolii. Oba numery wydane zostały w tym samym 1964 r. (czwarty na wiosnę, piąty na jesieni). W nawiązaniu do lotów w kosmos w grafice pop-artu i komiksu, wierząc w przekonanie, że rolą architektów

\footnotetext{
${ }^{6}$ Cezary Wąs, badając kierunek dekonstruktywizmu wg Jacquesa Derridy, pisał: „,Derrida często rozważał zagadnienie granic i ich przekraczania, a także rolę marginesów. W jego opinii wychodzenie poza przyjęte ramy dyscyplin było jedną z głównych strategii czy wręcz konieczności dekonstrukcji”.
} 
jest poszukiwanie nowych możliwości, członkowie grupy idą o krok do przodu i tworzą projekty jeszcze bardziej eksperymentalne i „rysują” najsłynniejsze swoje wizje. Najpierw punktem wyjściowym jest kapsuła do mieszkania (również w nr 6), która powinna być mobilna i zmienna. Kapsuła może lecieć w kosmos, może leżeć na dnie morza, może wisieć w powietrzu, gdzie tylko jej właściciel-mieszkaniec sobie wymarzy i zechce na chwilę osiąść. Punktem łączącym kapsuły byłaby wielka struktura Plug-in-City, do której każdy za pomocą specjalnego systemu gniazd i wtyczek, mógłby się podłączać w dowolnym miejscu.

Otwierając numer 4 pokazuje nam się stojąca płaska makieta czterech wież - jak w starej książce dla dzieci. Projekt nazwany POP-UP w nowy świat został przygotowany na międzynarodową wystawę w Montrealu w 1967 r. Wieża Warrena Chalka proponuje miasto przyszłości w formie obracających się pięter, z których każde jest spłaszczoną bańką w różnych kolorach kameleona. Wieża Rona Herrona jest kompleksem połączonych ze sobą tub-budynków chwytających światło z miejscem do grania i zabawy w pionowych trzonach. W wieży Franka Lindena widzimy czyste, metaliczne pionowe trzony z komunikacyjnymi węzłami w poziomie, do których pokoje rozrywek i kabiny mieszkalne są przyczepione ukośnie. Wieża Petera Cooka rozpościera się na siatce konstrukcji zasłoniętej przez zasłony, a ruch jest tu zawsze ukośny.

Mobilność oraz zmienność zaczęły być kluczowym efektem w działalności grupy. Cedrice Price - mentor Archigramu oraz dyrektor Architectural Association School of Architecture w Londynie w czasie studiów członków grupy - na łamach czasopisma prezentuje fragment Fun Palace $^{7}-$ w konstrukcji rusztowej wspartej na stalowych wieżach, między którymi wiszą tymczasowe gotowe obiekty połączone ruchomymi schodami, kładkami, windami, pochylniami i platformami - idealna przestrzeń widowiskowo-wystawiennicza.

Kolejna wizja miasta, która wydaje się już oczywista, to zaprojektowanie całej metropolii, która się przemieszcza. W 1964 r. Herron proponuje Walking City - mobilną gigantyczną konstrukcję, która przemierza morza i lądy na wielkich mechanicznych nogach, w poszukiwaniu idealnego miejsca do życia dla mieszkańców. Jak piszą w magazynie: „być może jest to propozycja dla światowej stolicy" [Grupa Archigram 1964, s. 8]. W przeciwieństwie do innego projektu Instant City - latającego miasta z usługami kulturalnymi i rozrywkowymi przeznaczonymi głównie dla małych miasteczek, które nie mają swojego centrum rozrywki.

Kolejną wariacją kapsuły jest Cushicle z numeru 8 (1968). Mniejsza i bardziej osiągalna, dostosowana do człowieka, mieszcząca się w plecaku, do nadmuchania $\mathrm{w}$ razie potrzeby. A także Suitaloon - przestrzenne ubranie, które po nadmuchaniu staje się minimalnym domem.

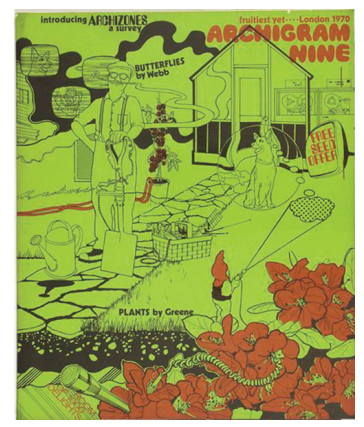

Ryc. 9. Okładka czasopisma

ARCHIGRAM nr 9, $1970 \mathrm{r}$.

Źródło: Archigram Archives, http://archigram.westminster.ac.uk/

\footnotetext{
${ }^{7}$ Była to główna inspiracja dla Centrum Georges Pompidou, w którym się mieści muzeum sztuki współczesnej oraz główna biblioteka publiczna stolicy Francji, budynek zaprojektowany przez Renzo Piano i Richarda Rogersa w drodze międzynarodowego konkursu architektonicznego.
} 
Poza optymizmem i wiarą w technologię, projekty które są prezentowane cechuje pewna logika przedstawionych nowych pomysłów. Autorzy są głęboko przekonani, że postęp daje ludziom większą swobodę i w związku z tym lepsze możliwości rozwoju. Zdają sobie sprawę, że ich architektura jest eksperymentalną formą realizowania wolności, mobilności. Widzą że są inni, którzy również mają odwagę prezentować prospołeczne, architektoniczne hasła. W numerze 6 - tym razem w op-artowej stylistyce czytamy w ich oryginalnym języku: „To jest pierwsza z nowych usług, dzięki której będziemy pamiętać imiona architektów, szczególnie za zasługi dla studentów" [Grupa Archigram 1965, s. 16]. W tym miejscu pada lista nazwisk ze świata, główne z Europy; ARCHIGRAM wspomina o Metabolizmie Japońskim, Constancie, oczywiście wymieniają siebie, a także Fredericka Kieslera czy Jerzego Sołtana - współpracownika Le Corbusiera.

Marzenia o mobilności spełniły się, kiedy członkowie grupy wygrali konkurs na centrum rozrywkowe w Monte Carlo. Zwycięski projekt przedstawiał kopułę zakopaną pod ziemia, a widownia, światła, stoliki a nawet toalety były zamontowane na kółkach tak, aby można było zmieniać ich pozycję w zależności od potrzeb; niestety, obiekt nigdy nie został zbudowany, gdyż nie było odpowiednich środków finansowych.

Warto wspomnieć, że kiedy magazyn sprzedawał się w tysiącach kopii pod koniec lat 60., wielu młodych, początkujących architektów miało szansę zostać zauważonym. ARCHIGRAM zapraszał do umieszczenia na swoich stronach projektów twórców takich jak: Nicholas Grimshaw, Hans Hollein, Frei Otto czy Arata Isozaki.

Niemniej jednak najważniejszą cechą ARCHIGRAMU są zagadnienia, które poruszali często w bardzo wyszukany graficzny sposób. Estetyka numerów, nawiązań graficznych do komiksu pop-artu, op-artu, Beatlesów, rozmiarów papieru, składanych, zszywanych, $\mathrm{z}$ dodatkami, np. opornikiem elektrycznym w numerze $7 \mathrm{w}$ związku z wynalezieniem

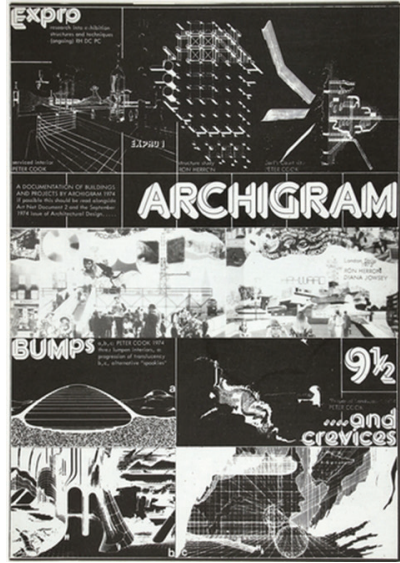

Ryc. 10. Okładka czasopisma ARCHIGRAM nr 9 1/2, 1974 r.

Źródło: Archigram Archives, http://archigram.westminster.ac.uk/ lasera i opornika, było odzwierciedleniem marzeń i dążeń do nowych rozwiązań. Eksperymenty architektoniczne, jakie zostały opisane na łamach magazynów w latach 1961-1974 znajdują odbiorców do dzisiaj i są realizowane $\mathrm{w}$ podobnej formie, np. kształt biblioteki z projektu nr $2 \mathrm{w}$ postaci szklanej piramidy widzimy na dziedzińcu muzeum Louvre, pomysł na wielopoziomowy parking połączony $\mathrm{z}$ centrum handlowo-rozrywkowym jest dzisiaj rzeczą oczywista, a taki projekt dyplomowy zaprezentował Michael Webb, o prowokacyjnej nazwie „Miasto grzechu”. Wpływ ARCHIGRAMU na sposób myślenia i postrzegania architektury dokładnie widać nie tylko u wcześniej wymienionych dekonstruktywistów, ale również u Rema Koolhaasa czy Zahy Hadid. Najwcześniejszym budynkiem, powstałym w myśl grupy i Cedrica Price'a, jest Centrum Pompidou autorstwa Richarda Rogersa i Renzo Piano. Analizując architekturę 
współczesną nie jest trudno zauważyć wpływ ARCHIGRAMU na dzisiejszych twórców. Z pewnością niektóre nawiązania są nieświadome, jak sama grupa nie do końca świadomie nawiązywała np. do Constanta, natomiast marzenia o zmiennym i mobilnym domu do dzisiaj są wciąż tylko marzeniem wielu twórców.

Warto podkreślić, że ARCHIGRAM opisywał nie tylko pojedyncze budynki, ale również całe złożone struktury urbanistyczne. Wizje miast i ich połączeń nie były bez znaczenia dla wyglądu i krajobrazu powstałego wskutek projektów. Miasta w postaci wież rozpostartych na siatkach, futurystyczne, zmieniające lokalizacje kapsuły mieszkalne przypominają sceny z filmów science-fiction. Dodatkowo mamy do czynienia z performatywnym podejściem do przestrzeni, ponieważ krajobraz w ARCHIGRAMIE jest stale zmienny, a patrząc na np. Walking City, wręcz ruchomy i przemieszczający się. Dzisiaj najważniejszą rzeczą w procesie myślenia o mieście nie jest człowiek - jak każdy sądzi, tylko zaawansowana sieć technologicznokomunikacyjna tworzona dla ludzi, aby życie było szybsze i łatwiejsze. Dokładnie to, co prezentowała grupa w swoich magazynach.

Dzięki grupie Archigram oraz ich czasopismom, pojęcie architektury eksperymentalnej stało się powszechnie znane. Inne postrzeganie architektury, ponowne definiowanie podstawowych pojęć, ogólna zmienność sytuacji społecznej spowodowała, że dzisiejsi twórcy eksperymentują w celu zaprojektowania jak najlepszego budynku w danym miejscu.

Artykuł pokazał, że pojęcie architektury eksperymentalnej (nieograniczonej) zostało wprowadzone i zapoczątkowane m.in. przez brytyjską grupę artystyczną Archigram w latach 60. ubiegłego wieku. Dzięki upublicznieniu materiałów źródłowych, w postaci dziesięciu magazynów wydanych przez grupę Archigram, możemy prześledzić proces kształtowania się zjawiska projektowania eksperymentalnego $\mathrm{w}$ architekturze i urbanistyce. Bunt lat 50. i 60., wyrażony za pomocą poszukiwań teorii lepszego życia znalazł odbicie i kontynuacje w architektonicznych fantazjach i marzeniach grupy Archigram. Ich utopijny charakter spowodował, że przez wiele lat pozostały one na marginesie świata architektury i urbanistyki. Jednakże ich odwaga i bezkompromisowość, nawet po wielu latach mogą być inspiracją dla twórczego myślenia w tych dziedzinach. Dlatego przypomnienie ich pomysłów i zaskakujących idei ma istotną wartość również w obecnym czasie. 


\section{Literatura}

Chtcheglov I. V., 1953, Formuła Nowego Urbanizmu, (tłum. C. Beb), Internationale Situationniste, 1, polskie tłumaczenie tekstu dostępne pod adresem: https://magivanga.wordpress. com/2012/04/26/formula-nowego-urbanizmu/, [dostęp 01.05.2018].

Fedders K., 2004, Archigram (tłum. własne) [w:] R.S. Sennott (red.), Encyclopedia of 20th-century architecture, s. 57.

Greene D., 1961, ARCHI(tektoniczny tele)GRAM nr 1 (tłum. własne), s. 1.

Grupa Archigram, 1963, ARCHIGRAM nr 3 (tłum. własne), s. 7.

Grupa Archigram, 1964, ARCHIGRAM nr 5 (tłum. własne), s. 8.

Grupa Archigram, 1965, ARCHIGRAM nr 6 (tłum. własne), s. 16.

Huizinga J., 1985, Homo ludens. Zabawa jako źródło kultury (tłum. M. Kurecka, W. Wirpsza), Czytelnik, Warszawa.

Debord G., 2006, Społeczeństwo spektaklu oraz Rozważania o społeczeństwie spektaklu (tłum. M. Kwaterko), PIW, Warszawa.

Nieuwenhuys C. A., znany jako Constant, 1998, New Babylon: Outline of a Culture 1960-1965, (tłum. własne) [w:] M. Wigley (red.), Constant’s New Babylon: The Hyper-Architecture of Desire, Witte de With CfCA / 010 Publishers, Rotterdam, s. 164.

Sartre J. P., 2007, Byt i nicość (tłum. J. Kiełbasa, P. Mróz, R. Abramciów, R. Ryziński, P. Małochleb), Wydawnictwo Zielona Sowa, Kraków.

Sullivan L. H., 1896, The Tall Office Building Artistically Considered, Lippincott's Magazine, 57, s. $403-409$.

Wąs C. 2010, W strone dekonstrukcji w architekturze, Quart. Kwartalnik Instytutu Historii Sztuki Uniwersytetu Wrocławskiego, 17, 3, s. 3-17.

Witruwiusz, 1956, O architekturze ksiag dziesięć (tłum. K. Kumaniecki), PWN, Warszawa. 


\section{Experimental architecture in city structures according to ARCHItecture teleGRAMs}

\section{ABSTRACT}

The article attempts to indicate the reasons for the development of experimental architecture in the second half of the twentieth century. During this time (after 1950), we can observe the activity of architects and artists through projects concerning life and thw feelings related to being here and now, and also to a large extent in the future. The reasons for the emergence of experimental projects are:

- dissatisfaction with life and the political situation - the term „,situation” has been described and deeply analyzed by Guy Debord, who founded the Situationist International (1957), and all descriptions are rebellious by nature,

- the emergence of a new philosophy of life, work and play (based on the book by Johan Huizinga Homo Ludens: A Study of the Play-Element in Culture - 1938),

- $\quad$ very rapid technological progress (strong belief in space flights, mobile homes, underwater life and new building materials etc.) - Ivan Chtcheglov is the author of the first description of a moving house dream in 1958.

The Archigram Group was established in 1961 based on the above. Over the next 13 years, this group published 10 issues of a magazine of the same name, which served as research material to analyze the development of thinking about experimental architecture. The group, through its texts, projects, and very interesting graphic design, was one of the first to showcase the other, experimental face of architecture and cities. The group spent all this time searching for an answer to the question: what should design look like to make life as comfortable as possible, and thus: happy. The group members did not acknowledge limitations in their futuristic projects and deeply believed that their implementation would be a matter of time. The more so, since the assumptions and concepts of the projects were very simple.

After analyzing the magazine issues and projects contained therein, we can see how large an impact the Archigram Group has had on contemporary projects. However, despite the huge technological progress, a changing and mobile home is still the dream of many creators.

Key words: Archigram, experimental architecture, situation, urban structures

\footnotetext{
Arkadiusz Sarlej, mgr inż. arch., asystent w Instytucie Architektury i Urbanistyki Politechnice Łódzkiej; interesuję się zagadnieniami zwiq̨zanymi z eksperymentem, performancem, mutacją w architekturze; członek Łódzkiej Okręgowej Izby Architektów; kontakt: IAiU, al. Politechniki 6a, 90-924 Łódź; e-mail:arkadiusz.sarlej@p.lodz.pI

Arkadiusz Sarlej, assistant in the Institute of Architecture and Urban Planning at the Lodz University of Technology; is interested in experiment, performance and mutation in architecture; member of the Lodz Chamber of Architects; contact: IAiU, al. Politechniki6a, 90-924 Lodz, email: arkadiusz.sarlej@p.lodz.pI
} 